\title{
THE TWIN FOCI OF ORGANISATIONAL IDENTIFICATION AND THEIR RELEVANCE FOR COMMITMENT: A STUDY OF MARKETING COMMUNICATIONS INDUSTRY
}

\author{
Klement PODNAR ${ }^{1}$, Urša GOLOB ${ }^{2}$ \\ Faculty of Social Sciences, University of Ljubljana, Kardeljeva pl. 5, \\ 1000 Ljubljana, Slovenia \\ E-mails: ${ }^{1}$ klement.podnar@fdv.uni-lj.si; ${ }^{2} u r s a . g o l o b @ f d v . u n i-l j . s i$ \\ (corresponding author)
}

Received 27 March 2012; accepted 28 March 2013

\begin{abstract}
The purpose of this paper is to distinguish the two foci of organisational identification and to explore relations among employees' groups and corporate identification, perceived external prestige, and organisational commitment. Structural equation modelling was applied to data collected by questionnaire from a sample of 145 respondents employed in advertising agencies, to test the relationships between the researched concepts. Organisational identification comprises identification with the organisation both as a collective of individuals and as a social entity. Perceived external prestige augments corporate identification and helps to explain organisational commitment. A strong positive link between corporate identification and organisational commitment was also found. The findings suggest a means for marketing strategists and general managers to predict the consequences of managing reputation for employees and to undertake appropriate initiatives to enhance corporate identification inside the company and thus influence organisational commitment and corporate performance.
\end{abstract}

Keywords: group and corporate identification, organisational identification, perceived external prestige, organisational commitment, marketing communications industry, structural equation modelling.

JEL Classification: M31.

\section{Introduction}

For numerous authors who specialise in strategic management and marketing as well as other academic disciplines dealing with companies and organisational realities, organisational identification is one of the root constructs in organisational phenomena (Albert et al. 2000). Authors argue that strong identity of an organisation - identity that increases the identification of employees - can indeed be an important competitive advantage (Podnar et al. 2011). Identification with an organisation can be seen as an antecedent to different behavioural outcomes of the employees related to stronger organisational commitment (Bergami, Bagozzi 2000). From a managerial perspective, 
identification is advantageous in ensuring that employees' decisions are congruent with organisational goals and the corporate brand, and are in the organisation's best interests (Miller et al. 2000). One way to achieve this is through recognition that individuals tend to identify with organisations, which are perceived to be prestigious, as this enhances their self-esteem (Fuller et al. 2006). This perceived status of the organisation that enhances the identification has been termed the perceived external prestige - PEP (Smidts et al. 2001). An empirical examination of these concepts is important for corporate marketing strategy, which is predicated on the notion that such concepts as identification and commitment inform our comprehension of the modern organisation (Balmer 2011). Furthermore, identification and commitment can be seen as internal resources for a holistic approach to corporate branding processes (Harris, de Chernatony 2001).

Despite consensus about organisational identification's importance and consequences, the literature on corporate marketing still lacks a fuller understanding of the construct, both in terms of its nature and its relation to commitment. The majority of research on identification has focused on the organisation as a holistic construct (Bartels et al. 2006) without an explanation how 'organisational identification' is construed: as a focus on group membership or a focus on belonging to the organisation as a social entity, a brand. Recently it has been verified that both foci exist and can be adopted by employees simultaneously (Podnar et al. 2011). Nevertheless, little is known about how a clear distinction between one focus and another enhances understanding of their antecedents such as PEP of the organisation, and consequences such as commitment.

Furthermore, while existing research has established that PEP is an important antecedent of organisational identification, only a few studies have addressed the relationship between PEP and commitment (e.g., Guerrero, Herrbach 2009). However, even those studies mostly reflect commitment's conceptual proximity to the identification, which has been only recently empirically differentiated from the commitment. In terms of better understanding of PEP as an antecedent in relation to both - identification and commitment, it is important to establish the conceptual distance between these two concepts. The distance is hidden in perceiving commitment as an attitudinal and behavioural concept referring to individual willingness and decisions to remain with an organisation.

Hence, the contribution of this paper over previous studies is to fill in the research gap by studying the simultaneous influence of PEP on different foci of organisational identification and such other organisational outcomes as commitment. Following this, the present study has three objectives: (1) to examine whether employees adopt both corporate and group focus of identification, (2) to test which focus is more beneficial for the organisation in terms of its relation to commitment and finally, (3) to explore how PEP influences identification with an organisation as an entity and, simultaneously, what is its relation to commitment. The relations between concepts will be examined using the structural equation modelling (SEM). SEM allows for simultaneous assessment of the quality of construct measurement in terms of reliability and validity, while at the same time estimating the strength of a relationship between constructs (Heinecke 2011: 65). The method is appropriate as the size of our sample ensures an adequate level of statistical power of the model (McQuitty 2004). 
The answers to the questions above will add to the body of knowledge on corporate marketing and corporate brand literature, where it has been emphasised how important it is to acknowledge the role of employees' perceptions and behaviour in the corporate brand building process (Harris, de Chernatony 2001), Additionally, from the corporate marketing perspective it is essential to study the notion of (multiple) identity-based views of the firm which simultaneously include identifications within the firm and with the firm or brand which can also be established via PEP (Balmer 2011), with PEP being a distinctive feature that provides a salient definition for organisational members (Mael, Ashforth 1992).

Our paper has potential contributions from the managerial perspective as well. In practitioner contexts it is increasingly acknowledged that organisations as entities, and corporate brands, have become means of differentiation and strategic resources for competitive advantage (Abratt, Kleyn 2012). Moreover, the importance of corporate identity and various forms of identifications is also growing (Balmer 2011). Hence, with addressing the above-stated objectives of our research this paper will provide some implications to the practitioners in terms of what activities in relation to employees work best to reinforce commitment, which can be seen as an internal resource for corporate branding.

\section{Theoretical background and hypotheses}

\subsection{The notion of organisation and the dual foci of identification}

Organisational identification can be described as a process of self-definition. This understanding has roots in social identity theory and social categorisation theory (Turner 1984; Tajfel, Turner 1986). The process of organisational identification is based on an individual sense of oneness with a particular social category and/or object. As such, organisational identification is perceived oneness with an organisation (Mael, Ashforth 1992) or as the cognitive connection between the definition of an organisation and the definition a person applies to him- or herself (Dutton et al. 1994).

Too often, however, scholars from different theoretical perspectives use the term organisational identification without explaining how they understand the term organisation itself. Authors use the same term (organisation) to describe two opposite views of organisation - as a group of employees where each individual matters (individualistic approach; Kaptein, Wempe 2002), and as an autonomous entity where a unitary view applies (collectivistic approach; Donaldson 1985). However, they fail to explain which one they are referring to. From the observer's perspective the first view is addressing the organisation with the word 'they', the second one, on the other hand, uses the term 'it' when describing the organisation (Podnar et al. 2011). These two perspectives are then reflected in conceptualising the identity of an organisation and identification with the organisation as well. Authors close to the collectivistic approach often refer to the identity of an organisation as 'corporate' (Balmer 2008) whereas authors streaming from an individualistic approach use the terms 'group identity' or even 'organisational identity' (Hatch, Schultz 2004). Both concepts form a coherent unit and point to the duality of organisation which is both a social aggregate on the one hand, and a 
monolithic social entity on the other, representing two foci of organisational identification (Podnar et al. 2011).

Although scholars tend to agree that there are multiple foci of organisational identification (Ashforth, Mael 1989; Ashforth, Johnson 2001), it has been only recently empirically verified that both foci can exist at the same level (Podnar et al. 2011). First, employees might form a psychological contract with the organisation as an entity resulting in 'corporate identification'. Second, employees perceive organisation through interactions with other workers, identifying with corporate culture (Balmer 2008), which leads to 'group identification'. It has been argued by Podnar et al. (2011) that focusing only on one aspect may result in serious omission both in terms of research and managerial practice. For example, neglecting the notion of group identification might cause a failure to recognise the importance of enhancing the sense of work community in an organisation, whilst failing to oversee corporate identification might lead to the insufficiency of strengthening the corporate brand.

\subsection{Organisational identification and commitment}

Early studies on organisational identification and commitment did not distinguish between the two concepts and referred to them as synonyms (e.g., Postmes et al. 2001). Barge and Schlueter (1988), Ashforth and Mael (1989) were the first who indicated this understanding might be misleading. Their argument is based on the notion that identification and commitment are two closely related but theoretically and empirically different concepts. According to Ashforth and Mael (1989), commitment can reflect individual goals that do not necessarily serve those of the collective as such, for example, an employee can be committed simply because the organisation is a convenient vehicle for personal career goals, while this may not be the case for identification. Furthermore, Van Knippenberg and Sleebos (2006) argue that the core difference between identification and commitment lies in the implied relationship between the individual and organisation. Identification reflects psychological oneness, whereas commitment reflects a relationship between separate psychological entities. Thus, commitment does not only reflect a psychological state of mind of an individual but has a rather more social nature.

As a specific form of social identification, organisational identification is defined as a feeling of sameness to an entity. Commitment on the other hand can be defined as a strong belief in and the acceptance of the organisation's goals and values, a willingness to exert considerable effort on behalf of the organisation and a desire to maintain membership in the organisation (Porter et al. 1974). According to Allen and Meyer (1990), different ways of defining commitment have in common a link with the fact that employees who are strongly committed are those who are least likely to leave an organisation. They explained it as mind-set that binds an individual to a course of action of relevance to one or more targets. For our purpose we understand organisational commitment as an individual willingness and decision to remain in an organisation.

More recent empirical studies support identification and commitment as being two distinct constructs (Riketta 2005; Cole, Bruch 2006; Van Knippenberg, Sleebos 2006). 
Furthermore, in some studies, identification is shown to have a positive relation with commitment (Bergami, Bagozzi 2000; Kwon et al. 2010), implicating that identifying with an organisation as such can be one of the primary motives for commitment (Becker 1992).

Previous studies have shown that employees are committed to the organisation as a whole, which is characterised with a strong wish to stay in the organisation (Herrbach, Mignonac 2004). As with corporate identification the 'object' of commitment is organisation as a social entity. Following this rationale and Becker's (1992) argument that embracement of the organisation through identification processes will likely lead to commitment, this implies that corporate identification and commitment may be positively related. However, when considering group identification and commitment the relation between the two concepts might not be as straightforward. The 'group' focus of identification relates to corporate cultural identification (Balmer 2008). Therefore, when organisation is seen as a work community the individuals might identify with it, however, this does not necessarily imply their automatic commitment to the organisation in terms of accepting its goals and values (Rock, Pratt 2002). Nevertheless, some studies have shown a positive relation between group identification and commitment (Mael, Ashforth 1995). Olkkonen and Lipponen (2006) found, for example, that when measuring organisational identification through the 'group' focus (i.e., employees talking about organisation as 'we'), identification is associated with organisationally relevant outcomes such as low turnover intentions. Therefore, we propose our two hypotheses:

H1a: An individual's corporate identification increases the extent of his/her organisational commitment.

H1b: An individual's group identification increases the extent of his/her organisational commitment.

\subsection{Perceived external prestige, identification and commitment}

People utilise their associations with organisations to define their self-concepts (Ashforth, Mael 1989). In this context, for individuals status-related issues in the organisations they belong to are particularly important and this is reflected in PEP (Dutton et al. 1994). PEP represents how an employee thinks and believes outsiders view his or her organisation and thus him or herself as a member of that organisation (Smidts et al. 2001). According to Dutton et al. (1994: 250), construed external image or PEP "summarises a member's beliefs about how people outside the organisation are likely to view the member through his or her organisational affiliation". As such, construed external image acts as a potentially powerful mirror, reflecting back to the members how the organisation and the behaviour of its members are likely to be seen by outsiders (Dutton et al. 1994). PEP is considered to be one of the most influential factors that positively affect organisational identification, since members feel proud to belong to an organisation that is believed to be reputable in public.

Empirical research supports this claim. Several studies found that members in an organisation who viewed the PEP of the firm highly attractive identified more strongly with their organisation than members in a matched firm where PEP was lower. The positive 
correlation between PEP and organisational identification was reported in several empirical studies (e.g., Bergami, Bagozzi 2000; Smidts et al. 2001; Carmeli, Freund 2002; Carmeli 2005; Riketta 2005; Fuller et al. 2006).

Although PEP is found to be positively associated with organisational identification the relation between PEP and commitment is not well developed and researched (Herrbach, Mignonac 2004). Carmeli and Freund (2002) were the first researchers to test the link between the two concepts. Their argumentation to link both concepts was build on the proposition that PEP as an output resource is most likely associated with organisational effectiveness, which is true also for commitment. They have confirmed a positive relation between affective dimension of commitment and PEP, but not between PEP and continuance commitment. In the second study dealing with PEP (Carmeli 2005) results indicated that PEP augments employees' affective commitment to their organisation. Herrbach and Mignonac (2004) similarly found that there is a positive relation between PEP and affective commitment. Furthermore, given that identification and commitment are strongly related concepts the knowledge about an established relationship between PEP and identification might suggest that PEP is an antecedent of commitment (Guerrero, Herrbach 2009). The following hypotheses are proposed:

H2: The higher the PEP of their organisation, the more strongly members will identify with it (in terms of corporate identification).

H3: The higher the PEP of their organisation, the higher employee's organisational commitment.

\section{Methodology}

\subsection{The measuring instruments}

Based on our deductive approach to study the particular relationships between variables we have used a quantitative survey strategy. Scales for the concepts were developed based on the past research described in the literature and were assessed on a five-point Likert scale normally used to measure opinion variables. Other scholars measuring the same theoretical concepts also used this type of scale.

Group identification, identification with the psychological group, was measured with the adapted measures (Henry et al. 1999). Internal consistency coefficients for these measures reported by Henry et al. (1999) were 0.85 (study 1) and 0.89 (study 2). Our adapted measures yielded similar results of the construct reliability $(\alpha=0.87)$. For corporate identification, defined as an individual sense of oneness with the company as an entity, we combined our own instrument using items from previous studies. The instrument was constructed from combining some of the items used by Henry et al. (1999) with the items adapted from other organisational identification measures that anchored towards corporate identification. Based on the review of all the appropriate measures, we generated a comprehensive item pool and reviewed the constituent items with two independent academics; to identify any that were unclear, biased, repetitive or otherwise unsuitable. Roughly one third of them were rejected. Prior to using the 
remainder of the suitable items in our questionnaire, the measures were tested on a sample of 89 employees from a middle-sized firm in the trade industry. The result was a one-dimensional and reliable construct $(\alpha=0.91)$. The construct in the present study was also proven to be reliable $(\alpha=0.94)$.

For measuring organisational commitment we adapted the Meyer and Allen's (1997) three-component model measuring affective, continuance and normative commitment. Based on the abovementioned conceptual distinction between identification and commitment two experts independently revised the original scale and excluded all items that measured identification with organisation. Factor analysis revealed three dimensions (normative, continuance and affective), which were then joined in a single variable of organisational commitment for the purposes of our research with a construct reliability of $\alpha=0.75$. It is known from the literature review described in our previous sections that affective dimension of commitment and identification are conceptually close. Therefore, to further distinct commitment from identification, a second-order variable of commitment (rather then its separate dimensions) was used in our model. The final variable in our model, $P E P$, was measured with the most common instrument recommended, tested and used by other authors (Mael, Ashforth 1992). Mael and Ashforth (1992) reported coefficient alpha was 0.77 in their study. In our case the construct was also one-dimensional and reliable $(\alpha=0.83)$.

\subsection{Data gathering}

The sampling frame for the primary sample was a list of the members of the Slovenian Advertising Chamber, which included approximately 400 employees of 40 marketing communications agencies. We selected the respondents within the individual agencies by systematic random sampling, with a sampling interval of 3 for the agencies and 2 for the respondents, to minimise selection bias and ensure as representative a sample as possible. The questionnaires were administrated personally, and data were collected from 200 employees of 12 agencies; $145(72 \%)$ of returned questionnaires were usable in the data analysis. Our sample is big enough for this kind of sampling frame and quite comparable to other studies on advertising agencies with sample sizes of around 130 (e.g., Erdogan, Tagg 2003; Schultz, Kitchen 1997).

\subsection{Sample characteristics}

The sample composition was $38 \%$ male and $62 \%$ female. Around $47 \%$ of employees were aged between $20-30$ years, while $32 \%$ were between $31-40$ years old. Although the respondents were fairly young, the sample is not biased as far as age is concerned and reflects the age structure of employees in advertising agencies rather well. Mahoney (2004) for example noted that the median age of employees in the U.S. advertising agencies is around 38 years. Almost half of the respondents in our survey possessed a graduate diploma. Among respondents $20.7 \%$ of them were employed as account directors, while smaller proportions of them were either chief executives $(4.8 \%)$, creative $(4.8 \%)$ or art directors (3.4\%). On average, they had worked for the examined agency for 4.1 years, with around $57 \%$ of the respondents having worked for the employer for over two years. 


\section{Empirical analysis}

\subsection{Descriptive statistics and measurement model}

Mean values show that, on average, all measures are quite high averaging above 3.0 on the 5-point Likert scales, the exception being commitment with a mean value slightly below 3.0 (Table 1). Correlations among all concepts are, as expected, positive and significant. PEP had the strongest relationship with corporate identification and a relatively strong one with commitment. The correlations of group identification with other variables tended to be the lowest although still statistically significant.

We further tested the measurement model with the Confirmatory Factor Analysis (CFA) using Lisrel 8.8 software. This was done in order to additionally test the reliability of measures via goodness-of-fit statistics for the overall model. For the purposes of CFA and structural modelling we selected three indicators for each latent variable. We selected them based on their high congruity with the defined factors (item-to-total correlations) and high inter-item correlations to further strengthen the convergent validity. CFA tests the scales simultaneously. Each item loads only on its respective latent variable. CFA results indicate that the measurement model fits the data rather well $\left(\chi^{2}=63.3\right.$; $\mathrm{df}=48$; RMSEA $=0.047$; CFI $=0.98)$. All loadings between indicators and latent variables are statistically significant $(\mathrm{p}<0.001)$. Standardised paths between latent variables and indicators are all above .50 (with the exception of one measuring commitment with the value of .30) and are thus meaningful (Chin 1998).

\subsection{Structural model and hypotheses tests}

Structural equation modelling tests the hypotheses concerning the key influences among latent variables. The fit indices for the structural model are essentially similar to CFA model and indicate a rather good model fit $(\chi 2=62.3$; $\mathrm{df}=48$; RMSEA $=0.047$; CFI $=$ 0.98). In the model we have also drawn a path between group and corporate identification as they are two foci of the same construct - organisational identification (Podnar et al. 2011). The parameter $\mathrm{R}^{2}$ is relatively high for all structural equations; $56 \%$ of variance in commitment is explained by PEP and group and corporate identification. Hence, the model has a relatively good predictability. Figure 1 summarises the results.

All hypothesized relations are statistically significant. Our results confirm the first hypothesis that corporate identification enhances commitment (H1a: Standardized Path

Table 1. Means, standard deviations, correlations and Cronbach's alphas

\begin{tabular}{lcccccc}
\hline Construct & $\mathrm{M}$ & $\mathrm{SD}$ & 1 & 2 & 3 & 4 \\
\hline Group identification & 3.60 & 0.71 & $(0.87)$ & & & \\
\hline Corporate identification & 3.57 & 0.84 & 0.39 & $(0.92)$ & & \\
\hline Perceived external prestige & 3.83 & 0.69 & 0.26 & 0.62 & $(0.82)$ & \\
\hline Organisational commitment & 2.92 & 0.67 & 0.27 & 0.69 & 0.43 & $(0.75)$ \\
\hline
\end{tabular}

Note: All correlations are significant at .01 level. 


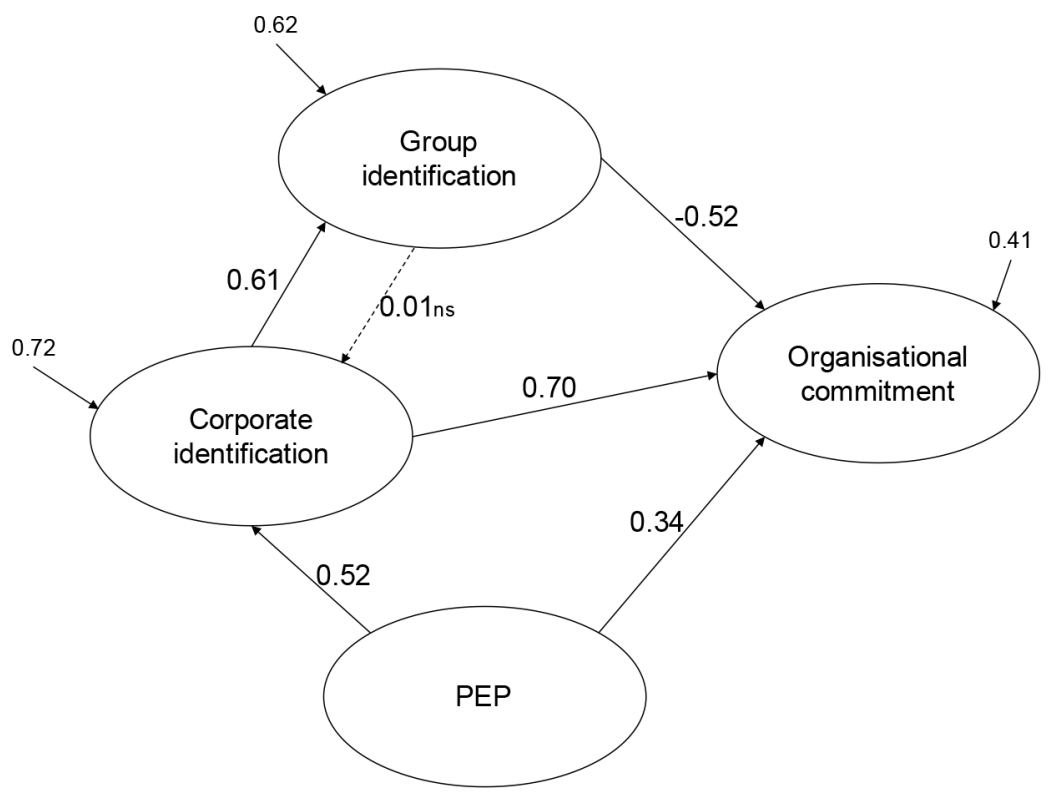

Fig. 1. Structural model - standardised paths among latent variables

Coefficient $(\mathrm{SPC})=0.70 ; \mathrm{t}=3.50 ; \mathrm{p}<0.001)$. However, group identification does not positively relate to commitment, contrary to our assumptions the relation has proven to be negative ( $\mathrm{H} 1 \mathrm{~b}$ : $\mathrm{SPC}=-0.52 ; \mathrm{t}=2.94 ; \mathrm{p}<0.001$ ). Results therefore do not support H1b. Furthermore, the results show that PEP has a relatively strong and positive influence on corporate identification $(\mathrm{H} 2: \mathrm{SPC}=0.52 ; \mathrm{t}=4.55 ; \mathrm{p}<0.001)$ and a fairly strong influence on commitment $(\mathrm{H} 3: \mathrm{SPC}=0.34 ; \mathrm{t}=2.39 ; \mathrm{p}<0.001)$. Thus the results confirm the hypotheses 2 and 3.

\subsection{Discussions and implications}

Our research showed that on one hand, a positive relation between a corporate focus of organisational identification and commitment exists. This confirms the arguments of other authors about the relationship between these two concepts (e.g., Ashforth, Mael 1989; Bergami, Bagozzi 2000). On the other hand, however, it was found that group identification is negatively related to commitment. This does not support our hypothesis and findings of Van Knippenberg and Van Shie (2000) investigating work-group identification and commitment. However, our result is not surprising given that identification with a "certain organisational focus may only predict outcomes relevant to it" (Olkkonen, Lipponen 2006: 205).

In particular, the theoretical implication of our study is that relevant outcomes for organisation are induced solely by corporate focus of identification, while group identification is not only irrelevant but also potentially contra-productive. Complementing this with a more practical view: if group identification is high in a particular organisation 
and corporate identification low, we can expect that such employees might not remain committed to the organisation.

Our last question in this study was how PEP influences corporate identification (an organisation as an entity) and commitment. Until now, the relations between PEP and identification and PEP and commitment were tested on a separate basis. Thus, our contribution advances the understanding of the link between PEP and corporate-focused identity construct such as commitment. The results show that PEP is indeed positively related to both, corporate identification and commitment. They also suggest a partly mediating influence of corporate identification on the relationship between PEP and commitment. This is indicated with the influence of PEP on commitment being lower while the relationships of corporate identification with PEP as well as commitment being quite strong. Such finding suggests that the effect of PEP on commitment can be explained in terms of the information PEP communicates about corporate identity.

A practical implication based on this would be that advertising agencies and organisations alike should therefore invest in their internal and external reputation and enhance corporate identification to retain employee commitment. Hence, according to the results of our study and previous research, high PEP as well as strong corporate identification can be helpful in motivating employees and fostering their commitment to the organisation.

Corporate identity and brand strategies can thus be effective ways to achieve organisational outcomes such as commitment. Such strategies include communicating and building a strong corporate brand internally and externally. Building brand internally demands excellent internal communication and high employee involvement to connect them to the corporate brand values, while building a strong external brand in order to enhance PEP must be based on a well developed corporate communications strategy. For employees a strong corporate brand can represent both, tangible benefits (coming from the internal reinforcement), and intangible meanings that shape their behaviour through identity effects from the external sources. In addition, our findings might be of particular interest for agencies in creative industries that tend to rely heavily on the staff and their performance to build a strong brand externally and in turn to enhance identification and commitment (Powell 2007).

\subsection{Limitations and suggestions for further research}

Lucas (2003) argues that external validity of study results is not so much a matter of methodological issues but a matter of theory. Nevertheless we would like to point out some possible limitations to the research. First, the respondents in the study were on average fairly young, which might affect the interpretation of the results concerning commitment. Although Giffords (2009) found that age was not a statistically significant variable to affect organisational commitment, a certain caution should nevertheless be exercised when considering generalising the results to other organisational settings. Another weakness related to our research setting is the fact that advertising agencies are a part of a knowledge-based expert sector, in which the employees of typically small firms are often more loyal to the industry as a whole than to a single employer (Powell, 
Ennis 2007). Additionally, the small size of these organisations implies that employees would tend to be more interconnected than in larger organisations. Consequently, group identification could have been confounded with work-group or work-team solidarity. This, however, generates opportunities for further research in terms of testing the identification measurement scale in larger organisations, or simultaneous exploration of lower-order varieties of identification such as work-group identification.

Furthermore, the relation between corporate brand and corporate and group identification would be an interesting focus for further research. Accordingly, what are the consequences for the organisation and individual if corporate identification and group identification are in a mutual conflict, if one prevails over the other? Our study also gives rise to the question of which level of organisational identification is more important in the sense of organisation management and success. The important question is also to what extent do individuals define themselves as either a collective or a social entity, or even both? This is important especially in the context of different types of organisations or/and cultures. We should also point out the significance of the company as a brand and the importance of communication between organisation and its members that should be researched further in the context of PEP, identification and commitment.

\section{Conclusions}

We believe that it is important for scholars and practitioners to understand the interplay of how antecedents related to external perceptions of corporate identity and multiplefoci of identification change organisational commitment. Our aim was to provide some insights into relations between these concepts by taking into consideration the dual nature of organisational identification. Despite some of the above-mentioned limitations, we believe our study makes a contribution in this regard. Our findings offer an additional empirical support to Ullrich et al. (2007) who argued for a separation of organisational identification into different foci. They also add to the Balmer's (2008) argument that at least two foci of higher-order identification coexist: 'group' relating to the identification with corporate culture, and 'corporate' representing identification with corporate identity, each having potentially different organisation-related outcomes.

\section{References}

Abratt, R.; Kleyn, N. 2012. Corporate identity, corporate branding and corporate reputations: reconciliation and integration, European Journal of Marketing 46(7/8): 1048-1063. http://dx.doi.org/10.1108/03090561211230197

Albert, S.; Ashforth, B. E.; Dutton, J. E. 2000. Organizational identity and identification: charting new waters and building new bridges, Academy of Management Review 25(1): 13-17.

http://dx.doi.org/10.5465/AMR.2000.2791600

Allen, J. N.; Meyer, J. P. 1990. The measurement and antecedents of affective, continuance and normative commitment to the organization, Journal of Occupational Psychology 63: 1-8. http://dx.doi.org/10.1111/j.2044-8325.1990.tb00506.x

Ashforth, B. E.; Mael, F. 1989. Social identity theory and the organization, Academy of Management Review 14(1): 20-39. 
Ashforth, E. B.; Johnson, S. A. 2001. Which hat to wear: the relative salience of multiple identities in organizational contexts', in M. A. Hogg, D. J. Terry (Eds.). Social identity processes in organizational contexts. Philadelphia: Psychological Press, 31-48.

Balmer, J. M. T. 2008. Commentary: identity based views of the organization, European Journal of Marketing 42(9/10): 879-906. http://dx.doi.org/10.1108/03090560810891055

Balmer, J. M. T. 2011. Corporate marketing myopia and the inexorable rise of a corporate marketing logic: perspectives from identity-based views of the firm, European Journal of Marketing 45(9/10): 1329-1352. http://dx.doi.org/10.1108/03090561111151781

Barge, K. J.; Schlueter, D. W. 1988. A critical evaluation of organizational commitment and identification, Management Communication Quarterly 2(1): 116-133.

http://dx.doi.org/10.1177/0893318988002001008

Bartels, J.; Pruyn, A.; de Jong, M.; Joustra, I. 2006. Multiple organizational identification levels and the impact of perceived external prestige and communication climate, Journal of Organizational Behavior 28(2): 173-190. http://dx.doi.org/10.1002/job.420

Becker, T. E. 1992. Foci and bases of commitment: are they distinctions worth making?, Academy of Management Journal 35(1): 232-244. http://dx.doi.org/10.2307/256481

Bergami, M.; Bagozzi, R. B. 2000. Self-categorization, affective commitment and group selfesteem as distinct aspects of social identity in the organization, British Journal of Social Psychology 39: 557-577. http://dx.doi.org/10.1348/014466600164633

Carmeli, A. 2005. Perceived external prestige, affective commitment, and citizenship behaviours, Organization Studies 26(3): 443-464. http://dx.doi.org/10.1177/0170840605050875

Carmeli, A.; Freund, A. 2002. The relationship between work and workplace attitudes and perceived external prestige, Corporate Reputation Review 5(1): 51-70.

http://dx.doi.org/10.1057/palgrave.crr.1540164

Chin, W. W. 1998. Issues and opinion on structural equation modelling, Management Information Systems Quarterly 22(1): 1-11.

Cole, M. S.; Bruch, H. 2006. Organizational identity strength, identification, and commitment and their relationships to turnover intention: does organizational hierarchy matter?, Journal of Organizational Behaviour 27(5): 585-605. http://dx.doi.org/10.1002/job.378

Donaldson, L. 1985. In defence of organizational theory: a reply to the critics. Cambridge: Cambridge University Press.

Dutton, J. E.; Dukerich, J.; Harquail, C. V. 1994. Organizational images and member identification, Administrative Science Quarterly 39: 239-263. http://dx.doi.org/10.2307/2393235

Erdogan, B. Z.; Tagg, S. 2003. The advertising agency manager's response patterns to a mail survey and follow-ups, Marketing Intelligence \& Planning 21(6): 392-399.

http://dx.doi.org/10.1108/02634500310499257

Fuller, J. B.; Hester, K.; Barnett, T.; Frey, L.; Relyea, C.; Beu, D. 2006. Perceived external prestige and internal respect: new insights into the organizational identification process, Human Relations 59: 815-846. http://dx.doi.org/10.1177/0018726706067148

Giffords, E. D. 2009. An examination of organizational commitment and professional commitment and the relationship to work environment, demographic and organizational factors, Journal of Social Work 9(4): 386-404. http://dx.doi.org/10.1177/1468017309346232

Guerrero, S.; Herrbach, O. 2009. Manager organizational commitment: a question of support or image?, The International Journal of Human Resource Management 20(7): 1536-1553.

http://dx.doi.org/10.1080/09585190902983496

Harris, F.; De Chernatony, L. 2001. Corporate branding and corporate brand performance, European Journal of Marketing 35(3/4): 441-456. http://dx.doi.org/10.1108/03090560110382101 
Hatch, M. J.; Schultz, M. 2004. Organizational identity. Oxford: Oxford University Press.

Heinecke, P. 2011. Success factors of regional strategies for multinational corporations, Contributions to Management Science. Berlin: Springer. http://dx.doi.org/10.1007/978-3-7908-2640-1

Henry, K. B.; Arrow, H.; Carini, B. 1999. A tripartite model of group identification, Small Group Research 30(5): 558-581. http://dx.doi.org/10.1177/104649649903000504

Herrbach, O.; Mignonac, K. 2004. How organisational image affects employee attitudes, Human Resource Management Journal 14(4): 76-88.

http://dx.doi.org/10.1111/j.1748-8583.2004.tb00134.x

Kaptein, M.; Wempe, J. 2002. The balanced company. Oxford: Oxford University Press. http://dx.doi.org/10.1093/acprof:oso/9780199255504.001.0001

Kwon, H. H.; Han, J. W.; Koh, E.; Han, S. 2010. Female dancers' organizational commitment: its relationship with organizational identification and job satisfaction in Korea, Asian Women 26(3): 51-71.

Lucas, J. W. 2003. Theory-testing, generalization, and the problem of external validity, Sociological Theory 21(3): 236-253. http://dx.doi.org/10.1111/1467-9558.00187

Mael, F. A.; Ashforth, B. E. 1992. Alumni and their alma mater: a partial test of the reformulated model of organizational identification, Journal of Organizational Behavior 13: 103-123.

http://dx.doi.org/10.1002/job.4030130202

Mael, F. A.; Ashforth, B. E. 1995. Loyal from day one: biodata, organizational identification, and turnover among newcomers, Personnel Psychology 48(2): 309-333.

http://dx.doi.org/10.1111/j.1744-6570.1995.tb01759.x

Mahoney, S. 2004. Does age matter?, Adweek, 5 April, 2004.

McQuitty, S. 2004. Statistical power and structural equation models in business research, Journal of Business Research 57(2): 175-183. http://dx.doi.org/10.1016/S0148-2963(01)00301-0

Meyer, J. P.; Allen, N. J. 1997. Commitment in the workplace: theory, research and application. Thousand Oaks: Sage.

Miller, V. D.; Allen, M.; Casey, M. K.; Johnson, J. R. 2000. Reconsidering the organizational identification questionnaire, Management Communication Quarterly 13(4): 626-658.

http://dx.doi.org/10.1177/0893318900134003

Olkkonen, M.; Lipponen, J. 2006. Relationships between organizational justice, identification with organization and work unit, and group-related outcomes, Organizational Behavior and Human Decision Processes 100(2): 202-215. http://dx.doi.org/10.1016/j.obhdp.2005.08.007

Podnar, K.; Golob, U.; Jančič, Z. 2011. Identification with an organisation as a dual construct, European Journal of Marketing 45(9/10): 1399-1415. http://dx.doi.org/10.1108/03090561111151826

Porter, L. W.; Steers, R. M.; Mowday, R. T. 1974. Organizational commitment, job satisfaction, and turnover among psychiatric technicians, Journal of Applied Psychology 59(5): 603-609. http://dx.doi.org/10.1037/h0037335

Postmes, T.; Tanis, M.; de Wit, B. 2001. Communication and commitment in organizations: a social identity approach, Group Processes \& Intergroup Relations 4(3): 227-246.

http://dx.doi.org/10.1177/1368430201004003004

Powell, S. 2007. Organisational marketing, identity and the creative brand, Journal of Brand Management 15(1): 41-56.

Powell, S.; Ennis, S. 2007. Organisational marketing in the creative industries, Qualitative Market Research 10(4): 375-389.

Riketta, M. 2005. Organizational identification: a meta-analysis, Journal of Vocational Behavior 66(2): 358-384. http://dx.doi.org/10.1016/j.jvb.2004.05.005 
Rock, W. K.; Pratt, M. 2002. Where do we go from here? Predicting identification among disperse employees, in B. Moingeon, G. Soenen (Eds.). Corporate and organizational identities. London: Routlege, 51-72.

Schultz, D. E.; Kitchen, P. J. 1997. Integrated marketing communications in US advertising agencies: an exploratory study, Journal of Advertising Research 37(5): 7-18.

Smidts, A.; Pruyn, A. T. H.; van Riel, C. B. M. 2001. The impact of employee communication and perceived external prestige on organizational identification, Academy of Management Journal 49(5): 1051-1062. http://dx.doi.org/10.2307/3069448

Tajfel, H.; Turner, J. 1986. The social identity theory of intergroup behaviour, in S. Worchel, W. G. Austin (Eds.). Psychology of intergroup relations. $2^{\text {nd }}$ ed. Chicago, IL: Nelson-Hall, 7-24.

Turner, J. C. 1984. Social identification and psychological group formation, in H. Tajfel (Ed.). The social dimension: European developments in social psychology. Cambridge: Cambridge University Press, 519-538.

Ullrich, J.; Wieseke, J.; Christ, O.; Schulze, M.; Van Dick, R. 2007. The identity-matching principle: corporate and organizational identification in a franchising system, British Journal of Management 18(Suppl. 1): S29-S44. http://dx.doi.org/10.1111/j.1467-8551.2007.00524.x

Van Knippenberg, D.; Sleebos, E. 2006. Organizational identification versus organizational commitment: self-definition, social exchange, and job attitudes, Journal of Organizational Behavior 27(5): 585-605. http://dx.doi.org/10.1002/job.359

Van Knippenberg, D.; Van Schie, E. C. M. 2000. Foci and correlates of organizational identification, Journal of Occupational and Organizational Psychology 73(2): 137-147.

http://dx.doi.org/10.1348/096317900166949

Klement PODNAR, Dr, Associate Professor, currently holds the position of a Vice-Dean at the Faculty of Social Sciences, University of Ljubljana. He gives lectures in Corporate Communication, International Marketing and Services Marketing. His research interests lie in corporate identity management, organizational identification, marketing and corporate communications. He has published several papers in this area European Journal of Marketing, Public Policy \& Marketing, The Service Industries Journal, and Journal of Business Research.

Urša GOLOB, Dr, Associate Professor. She teaches Marketing Management, Marketing Communications and Innovations and Economics of Marketing Communications at the Faculty of Social Sciences, University of Ljubljana. Her research interests focus on marketing management, corporate social responsibility and corporate communications. She publishes her papers in such journals as Transformations in Business \& Economics, European Journal of Marketing, Journal of Business Research, and Public Relations Review. 